\title{
Potential of using products containing amino acids in the protection of garden pansy (Viola wittrockiana) against pansy leaf anthracnose (Colletotrichum violae-tricoloris) and their impact on plant growth
}

\author{
Możliwość wykorzystania środków zawierających aminokwasy \\ w ochronie bratka ogrodowego (Viola wittrockiana) \\ przed Colletotrichum violae-tricoloris oraz ich wpływ na wzrost roślin
}

\author{
Adam T. Wojdyła*
}

\section{Summary}

The study evaluated the effects of plant growth promotor Agro-Sorb Folium and foliar fertilizers Agro-Sorb L-Amino ${ }^{+}$and Agro-Sorb Radiculum on the development of pansy leaf anthracnose caused by Colletotrichum violae-tricoloris. Agro-Sorb Folium and Agro-Sorb L-Amino+ ${ }^{+}$were applied 6 times at 7-day intervals in a greenhouse conditions at the concentrations of $0.25,0.5$ and $1 \%$. Their efficacy ranged from 48 to $61.7 \%$ and 40 to $61.7 \%$, respectively. Higher concentrations of the tested products increased their effectiveness. Agro-Sorb Radiculum used as a foliar treatment at $0.5 \%$ displayed an efficacy of approximately $57 \%$. The fertilizers Agro-Sorb L-Amino ${ }^{+}$and Agro-Sorb Radiculum applied 6 times as watering plants, showed an efficacy from $67 \%$ to $70.2 \%$ and from $57.5 \%$ to $65 \%$, respectively. All the tested products used for spraying or watering caused significant stimulation of the growth of pansy plants. None of the tested products caused changes in the appearance of the plants (phytotoxicity).

Key words: Colletotrichum violae-tricoloris; anthracnose; garden pansy; amino acids; effectiveness; spraying

\section{Streszczenie}

Oceniano wpływ stymulatora wzrostu roślin Agro-Sorb Folium, nawozów dolistnych Agro-Sorb L-Amino+ oraz Agro-Sorb Radiculum, stosowanych 6-krotnie co 7 dni do opryskiwania bratka ogrodowego uprawianego w szklarni, na rozwój objawów chorobowych powodowanych przez Colletotrichum violae-tricoloris. Agro-Sorb Folium oraz Agro-Sorb L-Amino+ stosowano w stężeniu 0,25, 0,5 oraz 1\%. Ich skuteczność wynosiła odpowiednio od 48 do $61,7 \%$ oraz 40 do 61,7\%. Wzrost stężenia badanych środków powodował zwiększenie ich skuteczności. Agro-Sorb Radiculum w stężeniu 0,5\% zastosowany do opryskiwania bratka, wykazywał około 57\% skuteczność. Nawozy Agro-Sorb L-Amino+ oraz Agro-Sorb Radiculum po 6-krotnym podlaniu bratka wykazywały skuteczność odpowiednio od 67 do 70,2\% oraz 57,5 do $65 \%$. Wszystkie badane środki stosowane do opryskiwania lub podlewania powodowały istotną stymulację wzrostu krzewów bratka. Żaden z badanych środków nie powodował zmian w wyglądzie bratka (fitotoksyczności).

Słowa kluczowe: Colletotrichum violae-tricoloris; antraknoza; bratek ogrodowy; aminokwasy; skuteczność; opryskiwanie

\footnotetext{
Instytut Ogrodnictwa

Konstytucji 3 Maja 1/3, 96-100 Skierniewice

*corresponding author: adam.wojdyla@inhort.pl
} 


\section{Wstęp / Introduction}

Leaf anthracnose caused by Colletotrichum violae-tricoloris R. E. Sm. is one of the most common and most serious diseases of pansy, occurring in both indoor and openfield cultivation. In landscape and greenhouse cultivation, severely infected pansies lose their decorative value, and may not be marketable at all. Considerable increases in the severity of disease symptoms have been recorded at high density planting in years with frequent rainfall. The number of products authorized for use in the protection of pansy against leaf anthracnose is low, and therefore, there is a risk of occurrence of $C$. violae-tricoloris resistance due to the absence of adequate rotation of protective agents. For this reason, it seems most appropriate to search for other means of protection.

The first reports concerning the possibility of using amino acids to induce plant resistance to pathogens are from the second half of the 20th century (Kuć et al. 1959). The authors demonstrated the resistance of apple cultivars susceptible to Venturia inaequalis after injecting the amino acid phenylalanine into their petioles. In subsequent years, there appeared studies on the possibility of using amino acids in plant protection against foliar and soil pathogens such as: Aphanomyces euteiches, Botrytis fabae, Cladosporium cucumerinum, Colletotrichum lagenarium, Erysiphe cichoracearum, Phytophthora infestans, Phytophthora cinnamomi, Puccinia recondita f. sp. tritici and Puccinia graminis f. sp. tritici, Fusarium oxysporum f. sp. lycopersici, Fusarium oxysporum f. sp. vasinfectum, Pyricularia oryzae (Van Andel 1966; Woltz and Jones 1970; Homma et al. 1973; Aly et al. 2010; Kadotani et al. 2016). The amino acid is absorbed by the cells and is easily engaged into the metabolic processes (Lipson and Nasholm 2001; El-Ghamry et al. 2009). Explaining the mechanism of action of amino acids on pathogens, Van Andel (1966) points out their fungicidal activity, reduction in pathogenicity, production of other compounds in soil or plant, disturbances in nitrogen metabolism, interference in the expression of symptoms, and increase in plant resistance to a specific pathogen. Hasabi et al. (2014), in a study of citrus bacterial canker (Xanthomonas citri subsp. citri), showed that amino acids (L-arginine, L-ornithine and L-methionine) used for spraying plants restricted the development of necrosis caused by that bacterium and affected the amounts in plant tissues of some enzymes such as catalase, peroxidase, phenylalanine ammonia-lyase, and $1,3-\beta$ glucanase. Among the tested amino acids, L-methionine showed the highest efficacy. The role of phenylalanine ammonia-lyase in inducing plant defense mechanisms is associated with the biosynthesis of phytoalexins, with the conversion of phenolic compounds to lignin-like substances, and with the induction of salicylic acid, which is involved in the transmission of signals inducing local and systemic resistance of the plant. Therefore, the level of activity of this enzyme is correlated with the degree of plant resistance to infection and the aggressiveness of the pathogen (Gałązka 2013).

Bakry and Rizk (1967) showed that amino acids directly affect spore germination, germ hypha elongation, and synthesis and activity of some enzymes responsible for the pathogenesis of Fusarium spp. In turn, Van Andel (1966) reported that various natural amino acids in vitro inhibited spore germination and growth of pathogen cultures while provided at high concentrations in the medium. Similarly, a previous study of ours assessed the influence of various concentrations of tested agents in potato-dextrose medium on the growth of Sclerotinia sclerotiorum cultures. When Agro-Sorb Folium, Agro-Sorb L-Amino ${ }^{+}$and Agro-Sorb Radiculum were applied at the concentration of $10000 \mu \mathrm{g} / \mathrm{ml}$ in the medium, an inhibition of the growth of cultures was $66.3,71.7$ and $40.4 \%$ respectively (Wojdyła and Sobolewski 2016).

The aim of the present study was to determine the effectiveness of selected products in reducing the development of leaf anthracnose (C. violae-tricoloris) in garden pansy and their effect on plant growth.

\section{Materiały i metody / Materials and methods}

The study included products whose main ingredient were free, natural (L- $\alpha$ ) amino acids (histidine, serine, arginine, glycine, aspartic acid, glutamic acid, threonine, alanine, proline, cysteine, lysine, tyrosine, methionine, valine, isoleucine, leucine, phenylalanine, tryptophan), i.e. plant growth promoter Agro-Sorb Folium $[12 \%$ total amino acids $(2.7 \%$ bound amino acids $+9.3 \%$ free amino acids $)+$ $2.1 \%$ total nitrogen $(\mathrm{N})+0.02 \%$ boron $(\mathrm{B})+0.05 \%$ manganese $(\mathrm{Mn})+0.07 \%$ zinc $(\mathrm{Zn})]$, organic fertilizer Agro-Sorb L-Amino ${ }^{+}[10 \%$ total amino acids $(5 \%$ bound amino acids + $5 \%$ free amino acids) $+2 \%$ total nitrogen $(\mathrm{N})+2 \%$ organic nitrogen $\left(\mathrm{N}_{\text {org }}\right)+4 \%$ organic carbon $\left(\mathrm{C}_{\text {org }}\right)+65 \%$ organic matter in dry weight], and organo-mineral fertilizer Agro-Sorb Radiculum [7\% total amino acids ( $1 \%$ bound amino acids $+6 \%$ free amino acids) $+2.9 \%$ total nitrogen $(\mathrm{N})+$ $1 \%$ phosphorus $\left(\mathrm{P}_{2} \mathrm{O}_{5}\right)+70 \%$ organic matter in dry weight $+20 \%$ dry weight] for spraying garden pansy cultivar Abendglut grown in a greenhouse. Garden pansies were planted in 1 litre containers placed on a windowsill in the greenhouse. During the experiment, the air humidity in the greenhouse was maintained at about $70 \%$, and the temperature varied between 16 and $20^{\circ} \mathrm{C}$. The plants were watered by stream of water directed onto topsoil in the pots or using the capillary matting system, which is designed to first absorb, then deliver water to the plants placed on the mat.

After the onset of disease symptoms, the tested products were applied 6 times at weekly intervals by spraying or watering the plants at the concentrations given in Table 1. Domark 100 EC (100 g tetraconazole in 11$)$ was used as the 
standard agent. The control plants were sprayed with water, and all the other ones with the tested products at various concentrations, using $100 \mathrm{ml}$ of liquid per $1 \mathrm{~m}^{2}$. For watering the plants, the amount of liquid used was $50 \mathrm{ml}$ per pot.

Severity of the disease symptoms was determined on an 8-point scale (Table 1,2) before the beginning of the experiment and 3 days after 2, 4 and 6 spray treatments. Observations of possible phytotoxicity of the tested products were carried out 3 days after each treatment and the assessment of the plants focused on signs of yellowing, browning of plant tissues, or growth inhibition.

After the completion of the experiments, the aboveground parts of the plants were separated, from the underground parts by a scalpel, and weighed to determine the fresh weight for each replication. After dividing the number of plants in each replication, fresh weight date was obtained for a single plant. Next, the aboveground parts from the individual replications were placed into envelopes and stored at $70^{\circ} \mathrm{C}$ for 24 hours in forced-air incubators. After 24 hours incubation period, the plant material was again weighed with and without envelopes. To obtain the dry weight per plant, the final dry weight of aboveground parts was divided by the number of plants in the replication (5). The experi- ments were set up in a completely randomized block design, in 4 replications with 5 pansy plants each. The data obtained were subjected to statistical analysis using Duncan's test. The percentage inhibition in the occurrence of the symptoms of leaf anthracnose was then calculated in relation to the control object (unprotected) using a simplified Abbott's formula (Abbott 1925).

\section{Wyniki i dyskusja / Results and discussion}

\section{Wpływ stymulatora wzrostu i badanych nawozów na ochronę bratka ogrodowego przed plamistością liści / Effect of the growth promoter and fertilizers tested on the protection of garden pansy against leaf anthracnose}

In the first greenhouse experiment, after 2 foliar treatments, the recorded degree of infection of the control plants was 1.9 (Table 1). The efficacy of Agro-Sorb Folium at the concentrations of $0.25,0.5$ and $1 \%$ in limiting the development of leaf anthracnose was from 84.2 to $89.5 \%$. AgroSorb L-Amino ${ }^{+}$, at the concentrations of $0.25,0.5$ and $1 \%$, showed an efficacy of about $89.5 \%$ in reducing the development of disease symptoms. An increase in the concentra-

Tabela 1. Skuteczność Agro-Sorb Folium, Agro-Sorb L-Amino+ oraz Agro-Sorb Radiculum w ograniczaniu rozwoju plamistości liści bratka ogrodowego odmiany Abendglut uprawianego w szklarni Początek doświadczenia i porażenie wstępne: $26.09 .2016=0,2$

Table 1. Effectiveness of Agro-Sorb Folium, Agro-Sorb L-Amino ${ }^{+}$and Agro-Sorb Radiculum in controlling the development of leaf anthracnose in garden pansy cultivar Abendglut grown in a greenhouse Experiment start date and initial severity of infection: $26.09 .2016=0.2$

\begin{tabular}{|c|c|c|c|c|c|c|c|}
\hline \multirow[t]{2}{*}{$\begin{array}{c}\text { Kombinacja } \\
\text { Treatment }\end{array}$} & \multirow[t]{2}{*}{$\begin{array}{c}\text { Stężenie } \\
\text { Concentration } \\
{[\%]}\end{array}$} & \multicolumn{3}{|c|}{$\begin{array}{c}\text { Stopień porażenia roślin } \\
\text { po opryskiwaniach } \\
\text { (w skali } 0-7 \text {-stopniowej) } \\
\text { Degree of infection after spraying } \\
\quad(0-7 \text { point scale) }\end{array}$} & \multicolumn{3}{|c|}{$\begin{array}{l}\text { Procentowa skuteczność } \\
\text { po opryskiwaniach } \\
\text { Percentage effectiveness } \\
\text { after spraying }\end{array}$} \\
\hline & & 2 & 4 & 6 & 2 & 4 & 6 \\
\hline Kontrola - Control & - & $1.90 \mathrm{~d}$ & $4.15 \mathrm{~g}$ & $5.00 \mathrm{i}$ & - & - & - \\
\hline Domark 100 EC & 0.05 & $0.20 \mathrm{ab}$ & $1.45 \mathrm{~d}$ & $2.00 \mathrm{c}$ & 89.5 & 65.1 & 60.0 \\
\hline Agro-Sorb Folium & 0.25 & $0.30 \mathrm{bc}$ & $2.05 \mathrm{f}$ & $2.60 \mathrm{~g}$ & 84.2 & 50.6 & 48.0 \\
\hline Agro-Sorb Folium & 0.5 & $0.25 \mathrm{a}-\mathrm{c}$ & $1.85 \mathrm{e}$ & $2.40 \mathrm{f}$ & 86.8 & 55.4 & 52.0 \\
\hline Agro-Sorb Folium & 1 & $0.20 \mathrm{ab}$ & $1.40 \mathrm{~d}$ & $2.20 \mathrm{e}$ & 89.5 & 66.3 & 56.0 \\
\hline Agro-Sorb L-Amino $^{+}$ & 0.25 & $0.20 \mathrm{ab}$ & $1.45 \mathrm{~d}$ & $3.00 \mathrm{~h}$ & 89.5 & 65.1 & 40.0 \\
\hline Agro-Sorb L-Amino $^{+}$ & 0.5 & $0.20 \mathrm{ab}$ & $1.05 \mathrm{~b}$ & $2.10 \mathrm{~d}$ & 89.5 & 74.7 & 58.0 \\
\hline Agro-Sorb L-Amino $^{+}$ & 1 & $0.20 \mathrm{ab}$ & $0.40 \mathrm{a}$ & $2.00 \mathrm{c}$ & 89.5 & 90.4 & 60.0 \\
\hline Agro-Sorb L-Amino ${ }^{+*}$ & $0.8 *$ & $0.15 \mathrm{a}$ & $0.40 \mathrm{a}$ & $1.65 \mathrm{a}$ & 92.1 & 90.4 & 67.0 \\
\hline Agro-Sorb Radiculum & 0.5 & $0.35 \mathrm{c}$ & $1.25 \mathrm{c}$ & $2.20 \mathrm{e}$ & 81.6 & 69.9 & 56.0 \\
\hline Agro-Sorb Radiculum* & $0.8^{*}$ & $0.30 \mathrm{bc}$ & $0.95 \mathrm{~b}$ & $1.75 \mathrm{~b}$ & 84.2 & 77.1 & 65.0 \\
\hline
\end{tabular}

*podlewanie - irrigation

Średnie w kolumnach oznaczone tą samą literą nie różnią się istotnie według testu Duncana przy $\mathrm{p}=0,05$

Means followed by the same letter in a column do not differ significantly according to Duncan's test at $\mathrm{p}=0.05$

Skala porażenia: 0 - brak objawów, 1 - do $1 \%$ powierzchni liści pokrytej plamami, 2 - 1,1 do 5\%, 3-5,1 do $10 \%, 4-10,1$ do $25 \%, 5$ - 25,1 do $50 \%$, 6 - 50,1 do 75\%, 7 - powyżej 75\% powierzchni liści pokrytej plamami

Infection severity scale: 0 - no symptoms, 1 - up to $1 \%$ of leaf surface area covered with lesions, $2-1.1$ to $5 \%, 3-5.1$ to $10 \%, 4-10.1$ to $25 \%, 5-$ 25.1 to $50 \%, 6-50.1$ to $75 \%, 7$ - more than $75 \%$ of leaf surface area covered with lesions 
tion of the tested growth promoter and fertilizer, used for spraying the pansies, was associated with an increase in their effectiveness. The Agro-Sorb Radiculum fertilizer at the concentration of $0.5 \%$ showed an efficacy of $81.6 \%$ in limiting the development of disease symptoms. Agro-Sorb L-Amino ${ }^{+}$ and Agro-Sorb Radiculum, applied 2 times for watering the plants, showed an efficacy of 92.1 and $84.2 \%$, respectively.

After 4 foliar treatments, the degree of infection of the control plants was 4.15 (Table 1). The efficacy of Agro-Sorb Folium at the concentrations of $0.25,0.5$ and $1 \%$ in limiting the development of disease symptoms was from 50.6 to $66.3 \%$. The efficacy of Agro-Sorb L-Amino ${ }^{+}$at the concentrations of $0.25,0.5$ and $1 \%$ ranged from 65.1 to $90.4 \%$. An increase in the concentration of the tested growth promoter and fertilizer, used for spraying the pansies, was associated with an increase in their effectiveness. The Agro-Sorb Radiculum fertilizer at the concentration of $0.5 \%$ showed an efficacy of about 70\%. Agro-Sorb L-Amino ${ }^{+}$and Agro-Sorb Radiculum applied 4 times for watering the plants showed an efficacy of 90.4 and $77.1 \%$, respectively.

After 6 foliar treatments, the degree of infection of the control plants was found to be 5.0 (Table 1). The efficacy of Agro-Sorb Folium at concentrations of $0.25,0.5$ and 1\% in limiting the development of disease symptoms was from 48 to $56 \%$, while Agro-Sorb L-Amino ${ }^{+}$used in those concentrations showed an efficacy from 40 to $60 \%$. An increase in the concentration of the tested growth promoter and fertilizer used for spraying the pansy plants was associated with an increase in their effectiveness. The Agro-Sorb Radiculum fertilizer at the concentration of $0.5 \%$ showed an efficacy of 56\%, while Agro-Sorb L-Amino and Agro-Sorb Radiculum used for watering the plants showed, after 6 treatments, an efficacy of 67 and $65 \%$, respectively.

In the second greenhouse experiment, after 2 foliar treatments, the degree of infection of the control plants was 2.55 (Table 2). Agro-Sorb Folium at the concentrations of $0.25,0.5$ and $1 \%$ showed an efficacy from 45.1 to $60.8 \%$ in limiting the development of disease symptoms. Agro-Sorb $\mathrm{L}-A m i n o^{+}$at the concentrations of $0.25,0.5$ and $1 \%$ had an efficacy from 39.2 to $56.9 \%$ in restricting the development of disease symptoms. An increase in the concentration of the tested growth promoter and fertilizer used for spraying the pansies was associated with an increase in their effectiveness. The Agro-Sorb Radiculum fertilizer at the concentration of $0.5 \%$ showed an efficacy of $60.8 \%$ in limiting the development of disease symptoms. Agro-Sorb L-Amino ${ }^{+}$

Tabela 2. Skuteczność Agro-Sorb Folium, Agro-Sorb L-Amino+ oraz Agro-Sorb Radiculum w ograniczaniu rozwoju plamistości liści bratka ogrodowego odmiany Acquarelle Felix White uprawianego w szklarni Początek doświadczenia i porażenie wstępne: $28 \cdot 10.2016=0,4$

Table 2. Effectiveness of Agro-Sorb Folium, Agro-Sorb L-Amino ${ }^{+}$and Agro-Sorb Radiculum in controlling the development of leaf anthracnose in garden pansy cultivar Acquarelle Felix White grown in a greenhouse Experiment start date and initial severity of infection: $28.10 .2016=0.4$

\begin{tabular}{|c|c|c|c|c|c|c|c|}
\hline \multirow[t]{2}{*}{$\begin{array}{c}\text { Kombinacja } \\
\text { Treatment }\end{array}$} & \multirow[t]{2}{*}{$\begin{array}{c}\text { Stężenie } \\
\text { Concentration } \\
{[\%]}\end{array}$} & \multicolumn{3}{|c|}{$\begin{array}{c}\text { Stopień porażenia roślin } \\
\text { po opryskiwaniach } \\
\text { (w skali } 0-7 \text {-stopniowej) } \\
\text { Degree of infection after spraying } \\
\quad(0-7 \text { point scale) }\end{array}$} & \multicolumn{3}{|c|}{$\begin{array}{l}\text { Procentowa skuteczność } \\
\text { po opryskiwaniach } \\
\text { Percentage effectiveness } \\
\text { after spraying }\end{array}$} \\
\hline & & 2 & 4 & 6 & 2 & 4 & 6 \\
\hline Kontrola - Control & - & $2.55 \mathrm{f}$ & $4.15 \mathrm{~h}$ & $4.70 \mathrm{f}$ & - & - & - \\
\hline Domark $100 \mathrm{EC}$ & 0.05 & $0.40 \mathrm{a}$ & $1.00 \mathrm{a}$ & $1.40 \mathrm{a}$ & 84.3 & 75.9 & 70.2 \\
\hline Agro-Sorb Folium & 0.25 & $1.40 \mathrm{~d}$ & $2.00 \mathrm{f}$ & $2.10 \mathrm{de}$ & 45.1 & 51.8 & 55.3 \\
\hline Agro-Sorb Folium & 0.5 & $1.20 \mathrm{c}$ & $1.80 \mathrm{e}$ & $1.85 \mathrm{~b}$ & 52.9 & 56.6 & 60.6 \\
\hline Agro-Sorb Folium & 1 & $1.00 \mathrm{~b}$ & $1.70 \mathrm{~d}$ & $1.80 \mathrm{~b}$ & 60.8 & 59.0 & 61.7 \\
\hline Agro-Sorb L-Amino $^{+}$ & 0.25 & $1.55 \mathrm{e}$ & $2.20 \mathrm{~g}$ & $2.20 \mathrm{e}$ & 39.2 & 47.0 & 53.2 \\
\hline Agro-Sorb L-Amino $^{+}$ & 0.5 & $1.20 \mathrm{c}$ & $1.85 \mathrm{e}$ & $1.90 \mathrm{bc}$ & 52.9 & 55.4 & 59.6 \\
\hline Agro-Sorb L-Amino ${ }^{+}$ & 1 & $1.10 \mathrm{bc}$ & $1.60 \mathrm{c}$ & $1.80 \mathrm{~b}$ & 56.9 & 61.4 & 61.7 \\
\hline Agro-Sorb L-Amino ${ }^{+*}$ & $0.8^{*}$ & $1.00 \mathrm{~b}$ & $1.25 \mathrm{~b}$ & $1.40 \mathrm{a}$ & 60.8 & 69.9 & 70.2 \\
\hline Agro-Sorb Radiculum & 0.5 & $1.00 \mathrm{~b}$ & $1.80 \mathrm{e}$ & $2.00 \mathrm{~cd}$ & 60.8 & 56.6 & 57.5 \\
\hline Agro-Sorb Radiculum* & $0.8 *$ & $1.40 \mathrm{~d}$ & $1.60 \mathrm{c}$ & $2.00 \mathrm{~cd}$ & 84.3 & 61.4 & 57.5 \\
\hline
\end{tabular}

*podlewanie - irrigation

Średnie w kolumnach oznaczone tą samą literą nie różnią się istotnie według testu Duncana przy p $=0,05$

Means followed by the same letter in a column do not differ significantly according to Duncan's test at $\mathrm{p}=0.05$

Skala porażenia: 0 - brak objawów, 1 - do $1 \%$ powierzchni liści pokrytej plamami, $2-1,1$ do $5 \%, 3-5,1$ do $10 \%, 4-10,1$ do $25 \%, 5$ - 25,1 do $50 \%$, 6 - 50,1 do $75 \%, 7$ - powyżej $75 \%$ powierzchni liści pokrytej plamami

Infection severity scale: 0 - no symptoms, 1 - up to $1 \%$ of leaf surface area covered with lesions, $2-1.1$ to $5 \%, 3-5.1$ to $10 \%, 4-10.1$ to $25 \%, 5-$ 25.1 to $50 \%, 6-50.1$ to $75 \%, 7-$ more than $75 \%$ of leaf surface area covered with lesions 
and Agro-Sorb Radiculum used for watering the plants restricted the development of the disease by 60.8 and $84.3 \%$, respectively, after 2 treatments.

After 4 foliar treatments, the degree of infection of the control plants was found to be 4.15 (Table 2). The efficacy of Agro-Sorb Folium at the concentrations of 0.25, 0.5 and $1 \%$ in limiting the development of disease symptoms was from 51.8 to $59 \%$. The efficacy of Agro-Sorb L-Amino ${ }^{+}$at the concentrations of $0.25,0.5$ and $1 \%$ ranged from 47 to $61.4 \%$. An increase in the concentration of the tested growth promoter and fertilizer used for spraying the pansy plants was associated with an increase in their effectiveness. The Agro-Sorb Radiculum fertilizer at the concentration of $0.5 \%$ showed an efficacy of 56.6\%, while Agro-Sorb L-Amino and Agro-Sorb Radiculum used for watering the plants showed, after 4 treatments, an efficacy of 69.9 and $61.4 \%$, respectively.

After spraying the pansies 6 times, the degree of infection of the control plants was 4.7 (Table 2). The efficacy of Agro-Sorb Folium at the concentrations of $0.25,0.5$ and $1 \%$ ranged from 55.3 to $61.7 \%$. Agro-Sorb L-Amino ${ }^{+}$at the concentration of $0.25,0.5$ and $1 \%$ showed an efficacy from 53.2 to $61.7 \%$ in limiting the development of disease symptoms. An increase in the concentration of the tested growth promoter and fertilizer used for spraying the pansies was associated with an increase in their effectiveness. The Agro-Sorb Radiculum fertilizer at the concentration of $0.5 \%$ had an efficacy of $57.5 \%$ in limiting the development of disease symptoms. Agro-Sorb L-Amino and Agro-Sorb Radiculum used for watering the plants 6 times restricted the development of disease symptoms by 70.2 and $57.5 \%$, respectively.

The relatively high effectiveness of the tested products containing amino acids has confirmed the results of the previous studies in which Agro-Sorb Folium, Agro-Sorb $\mathrm{L}-A m i n o^{+}$and Agro-Sorb Radiculum at the concentrations of $0.25,0.5$ and $1 \%$ used for spraying greenhouse-grown roses 4 times at 7-day intervals showed an efficacy from 64 to $98 \%$ in limiting the development of powdery mildew caused by Podosphaera pannosa (Wojdyła 2017). An increase in their concentration resulted in an increase in their effectiveness. Agro-Sorb Radiculum used at the concentration of $0.5 \%$ for spraying roses had an efficacy of about $85 \%$. The fertilizers Agro-Sorb L-Amino ${ }^{+}$and Agro-Sorb Radiculum showed an efficacy of 21.7 and $64 \%$, respectively, after watering the roses 2 times, and 10 and $17 \%$, respectively, after 4 watering treatments (Wojdyła 2017). Similarly, high effectiveness of the above products was demonstrated in the field studies in the protection of string beans against S. sclerotiorum (Wojdyła and Sobolewski 2016). In the study by these authors, Agro-Sorb Folium, Agro-Sorb L-Amino ${ }^{+}$ and Agro-Sorb Radiculum at the concentrations of 0.25 , 0.5 and $1 \%$ applied 4 times at 7 -day intervals for spraying string beans showed an efficacy from 57.9 to $81.3 \%$ in re- ducing the symptoms of rot caused by S. sclerotiorum. An increase in the concentration of the tested products increased their effectiveness. Agro-Sorb Radiculum at the concentration of $0.5 \%$ used for spraying beans showed an efficacy of over $52 \%$. Based on literature data it can be suggested that the amino acids present in the tested products interacted with the pathogen directly and by inducing resistance. The studies in which the authors had demonstrated the possibility of direct action of amino acids on some pathogens, including Fusarium spp. and S. sclerotiorum (Bakry and Rizk 1967; Wojdyła and Sobolewski 2016) confirmed these findings. In turn, the development of acquired resistance in plants following the use of amino acids had been pointed out by Kuć et al. (1959) and Mehta et al. (1991). Similarly, the induction of resistance in plants resulting from the application of amino acids had been demonstrated in the protection of pumpkin, pea, melon and strawberry against powdery mildew (Tzeng et al. 1996) and against downy mildew in pearl millet (Sarosh et al. 2005). However, the literature data regarding the possibility of using amino acids as inducers of plant resistance are very limited (Hasabi et al. 2014).

\section{Wpływ stymulatora wzrostu i badanych nawozów na wzrost roślin / Influence of the tested growth promoter and fertilizers on plant growth}

In the first experiment, it was found that the plants sprayed with Agro-Sorb Folium, Agro-Sorb L-Amino ${ }^{+}$ and Agro-Sorb Radiculum at the concentrations tested had a significantly higher fresh weight of aboveground parts, ranging from 21 to $36.4 \%$, in comparison with the control plants (Table 3). By far the highest fresh weight of the aboveground parts of pansies was found for the plants watered with Agro-Sorb L-Amino ${ }^{+}$and Agro-Sorb Radiculum, which was greater than in the control plants by 39 to $45.2 \%$. A similar relationship was found for the dry weight of the aboveground parts of pansy plants (Table 4). At the concentrations tested, a dry weight of aboveground parts of the plants sprayed with Agro-Sorb Folium, Agro-Sorb L-Amino ${ }^{+}$and Agro-Sorb Radiculum was by 16.9 to $37.1 \%$ higher than the control plants (Table 4). The highest dry weight of aboveground parts was found for the plants watered with Agro-Sorb $\mathrm{L}-A m i n o^{+}$and Agro-Sorb Radiculum, which was greater by 38.2 to $50.6 \%$ compared with the control plants.

In the second experiment, it was found that the pansy plants sprayed with the Agro-Sorb Folium growth promoter had, at each concentration tested, by 1.6 to $5.8 \%$ greater fresh weight of aboveground parts compared with the control plants (Table 3). As for the fertilizer Agro-Sorb L-Amino ${ }^{+}$treatment, an increase in the fresh weight of aboveground parts was recorded only when the product was applied at the concentration of $0.5 \%$. For the other tested concentrations of Agro-Sorb L-Amino ${ }^{+}$and 
Tabela 3. Wpływ stymulatora wzrostu Agro-Sorb Folium oraz nawozów Agro-Sorb L-Amino i Agro-Sorb Radiculum na świeżą masę roślin bratka ogrodowego w doświadczeniach

Początek doświadczenia: 26.09.2016

Table 3. Effect of Agro-Sorb Folium growth promotor and Agro-Sorb L-Amino ${ }^{+}$and Agro-Sorb Radiculum fertilizers on the fresh weight of garden pansy plants in the experiments Experiment start date: 26.09 .2016

\begin{tabular}{|c|c|c|c|c|c|}
\hline \multirow[t]{2}{*}{$\begin{array}{c}\text { Kombinacja } \\
\text { Treatment }\end{array}$} & \multirow{2}{*}{$\begin{array}{c}\text { Stężenie } \\
\text { Concentration } \\
{[\%]}\end{array}$} & \multicolumn{2}{|c|}{$\begin{array}{c}\text { Średnia świeża masa części } \\
\text { nadziemnych rośliny } \\
\text { Mean fresh weight } \\
\text { of aboveground parts } \\
{[\mathrm{g}]}\end{array}$} & \multicolumn{2}{|c|}{$\begin{array}{l}\text { Procentowy wzrost świeżej masy części } \\
\text { nadziemnych rośliny } \\
\text { Percentage increase in fresh weight } \\
\text { of aboveground parts }\end{array}$} \\
\hline & & $\begin{array}{l}\text { doświadczenie } \\
\text { experiment } \\
\text { I }\end{array}$ & $\begin{array}{l}\text { doświadczenie } \\
\text { experiment } \\
\text { II }\end{array}$ & $\begin{array}{l}\text { doświadczenie } \\
\text { experiment } \\
\text { I }\end{array}$ & $\begin{array}{l}\text { doświadczenie } \\
\text { experiment } \\
\text { II }\end{array}$ \\
\hline Kontrola - Control & - & $6.29 \mathrm{a}$ & $7.03 \mathrm{~cd}$ & - & - \\
\hline Domark $100 \mathrm{EC}$ & 0.05 & $6.01 \mathrm{a}$ & $8.64 \mathrm{~h}$ & -4.5 & 22.9 \\
\hline Agro-Sorb Folium & 0.25 & $7.66 \mathrm{~b}$ & $7.44 \mathrm{f}$ & 21.8 & 5.8 \\
\hline Agro-Sorb Folium & 0.5 & $8.53 \mathrm{~cd}$ & $7.35 \mathrm{ef}$ & 35.6 & 4.6 \\
\hline Agro-Sorb Folium & 1 & $8.37 \mathrm{c}$ & $7.14 \mathrm{c}-\mathrm{e}$ & 33.1 & 1.6 \\
\hline Agro-Sorb L-Amino $^{+}$ & 0.25 & $7.64 \mathrm{~b}$ & $5.33 \mathrm{a}$ & 21.5 & -24.2 \\
\hline Agro-Sorb L-Amino $^{+}$ & 0.5 & $8.35 \mathrm{c}$ & $7.22 \mathrm{~d}-\mathrm{f}$ & 32.8 & 2.7 \\
\hline Agro-Sorb L-Amino $^{+}$ & 1 & $7.61 \mathrm{~b}$ & $6.89 \mathrm{c}$ & 21.0 & -2.0 \\
\hline Agro-Sorb L-Amino ${ }^{+*}$ & $0.8^{*}$ & $9.13 \mathrm{e}$ & $9.06 \mathrm{i}$ & 45.2 & 28.9 \\
\hline Agro-Sorb Radiculum & 0.5 & $8.58 \mathrm{~cd}$ & $6.24 b$ & 36.4 & -11.2 \\
\hline Agro-Sorb Radiculum* & $0.8^{*}$ & $8.74 \mathrm{~d}$ & $8.27 \mathrm{~g}$ & 39.0 & 17.6 \\
\hline
\end{tabular}

*podlewanie - irrigation

Średnie w kolumnach oznaczone tą samą literą nie różnią się istotnie według testu Duncana przy p $=0,05$

Means followed by the same letter in a column do not differ significantly according to Duncan's test at $\mathrm{p}=0.05$

Tabela 4. Wpływ stymulatora wzrostu Agro-Sorb Folium oraz nawozów Agro-Sorb L-Amino+ i Agro-Sorb Radiculum na suchą masę części nadziemnych roślin bratka ogrodowego w doświadczeniach Początek doświadczenia: 28.10.2016

Table 4. Effect of Agro-Sorb Folium growth promotor and Agro-Sorb L-Amino ${ }^{+}$and Agro-Sorb Radiculum fertilizers on the dry weight of the aboveground parts of garden pansy plants in the experiments Experiment start date: 28.10 .2016

\begin{tabular}{|c|c|c|c|c|c|}
\hline \multirow[t]{2}{*}{$\begin{array}{l}\text { Kombinacja } \\
\text { Combination }\end{array}$} & \multirow{2}{*}{$\begin{array}{c}\text { Stężenie } \\
\text { Concentration } \\
{[\%]}\end{array}$} & \multicolumn{2}{|c|}{$\begin{array}{c}\text { Średnia sucha masa części } \\
\text { nadziemnych rośliny } \\
\text { Mean dry weight } \\
\text { of aboveground parts } \\
\text { [g] }\end{array}$} & \multicolumn{2}{|c|}{$\begin{array}{l}\text { Procentowy wzrost suchej masy części } \\
\text { nadziemnych rośliny } \\
\text { Percentage increase in dry weight } \\
\text { of aboveground parts }\end{array}$} \\
\hline & & $\begin{array}{l}\text { doświadczenie } \\
\text { experiment } \\
\text { I }\end{array}$ & $\begin{array}{l}\text { doświadczenie } \\
\text { experiment } \\
\text { II }\end{array}$ & $\begin{array}{l}\text { doświadczenie } \\
\text { experiment } \\
\text { I }\end{array}$ & $\begin{array}{l}\text { doświadczenie } \\
\text { experiment } \\
\text { II }\end{array}$ \\
\hline Kontrola - Control & - & $0.89 \mathrm{~b}$ & $0.99 \mathrm{~b}$ & - & - \\
\hline Domark $100 \mathrm{EC}$ & 0.05 & $0.83 \mathrm{a}$ & $1.21 \mathrm{e}$ & -6.7 & 22.2 \\
\hline Agro-Sorb Folium & 0.25 & $1.04 \mathrm{c}$ & $1.10 \mathrm{~cd}$ & 16.9 & 11.1 \\
\hline Agro-Sorb Folium & 0.5 & $1.13 \mathrm{~d}$ & $1.13 \mathrm{~d}$ & 21.2 & 14.1 \\
\hline Agro-Sorb Folium & 1 & $1.19 \mathrm{ef}$ & $1.09 \mathrm{~cd}$ & 33.7 & 10.1 \\
\hline Agro-Sorb L-Amino $^{+}$ & 0.25 & $1.06 \mathrm{c}$ & $0.94 \mathrm{a}$ & 19.1 & -5.1 \\
\hline Agro-Sorb L-Amino $^{+}$ & 0.5 & $1.22 \mathrm{fg}$ & $1.11 \mathrm{~cd}$ & 37.1 & 12.1 \\
\hline Agro-Sorb L-Amino ${ }^{+}$ & 1 & $1.06 \mathrm{c}$ & $1.09 \mathrm{c}$ & 19.1 & 10.1 \\
\hline Agro-Sorb L-Amino* & $0.8^{*}$ & $1.23 \mathrm{~g}$ & $1.29 \mathrm{f}$ & 38.2 & 30.3 \\
\hline Agro-Sorb Radiculum & 0.5 & $1.17 \mathrm{e}$ & $0.94 \mathrm{a}$ & 32.6 & -5.1 \\
\hline Agro-Sorb Radiculum* & $0.8^{*}$ & $1.34 \mathrm{~h}$ & $1.28 \mathrm{f}$ & 50.6 & 29.3 \\
\hline
\end{tabular}

*podlewanie - irrigation

Średnie w kolumnach oznaczone tą samą literą nie różnią się istotnie według testu Duncana przy $\mathrm{p}=0,05$

Means followed by the same letter in a column do not differ significantly according to Duncan's test at $\mathrm{p}=0.05$ 
Agro-Sorb Radiculum, the fresh weight of aboveground parts was found to be lower than in the control plants. By far the highest fresh weight of the aboveground parts of pansy plants was found in plants watered with Agro-Sorb

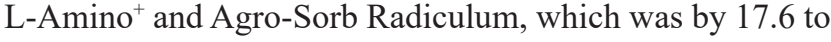
$28.9 \%$ greater than in the control plants. A similar relationship was found for the dry weight of the aboveground parts of the plants (Table 4). The plants sprayed with Agro-Sorb Folium at all concentrations and Agro-Sorb L-Amino ${ }^{+}$at the concentrations of 0.5 and $1.0 \%$ showed by 10.1 to $14.1 \%$ greater dry weight of aboveground parts compared with the control plants (Table 4). Spraying the plants with Agro-Sorb $\mathrm{L}-A m i n o^{+}$at the concentration of $0.25 \%$ and Agro-Sorb Radiculum at the concentration of $0.5 \%$ resulted even in a lower dry weight compared with the control plants. The highest dry weight of the aboveground parts of the pansy plants was found after watering them with Agro-Sorb $\mathrm{L}-A m i n o^{+}$and Agro-Sorb Radiculum, which was by about $30 \%$ greater than that of the control plants.

The experiments showed a varied significant effect of the pansy cultivar on plant stimulation. Of the cultivars tested, the cultivar Abendglut was particularly responsive to growth stimulation. Application of the products by watering proved to be significantly more effective in stimulating plant growth than application by spraying. The results obtained have confirmed the author's previous studies, in which all the tested products used for spraying or watering caused significant stimulation of the growth of rose bushes (Wojdyła 2017). The tested amino acids or foliar fertiliz- ers, due to their activity as promoters of plant growth and development, and also as inhibitors of the development of many foliar pathogens, are suitable for use in the integrated protection of pansy plants against diseases.

\section{Wnioski / Conclusions}

1. The plant growth promoter Agro-Sorb Folium and the fertilizers Agro-Sorb L-Amino ${ }^{+}$and Agro-Sorb Radiculum, the main ingredient of which are amino acids, when used 6 times at 7-day intervals to protect pansy plants, proved to be highly effective in limiting the development of leaf anthracnose caused by $C$. violae-tricoloris.

2. An increased concentration of Agro-Sorb Folium and Agro-Sorb L-Amino ${ }^{+}$resulted in higher efficacy of tested products.

3. The fertilizers Agro-Sorb L-Amino ${ }^{+}$and Agro-Sorb Radiculum applied by watering pansy plants 6 times showed an efficacy of several tens of percent in restricting the development of leaf anthracnose.

4. The tested growth promoter and fertilizers, used for spraying or watering, caused significant stimulation of the growth of pansy plants.

5. The tested growth promoter and fertilizers, used for spraying or watering, did not cause any phytotoxicity and none changes in the appearance of pansy plants were observed.

\section{Literatura / References}

Abbott W.S. 1925. A method of computing the effectiveness of an insecticide. Journal of Economic Entomology 18 (2): 265-267. DOI: 10.1093/jee/18.2.265a.

Aly A.A., Hussein E.M., Omar M.R., Abd-Elsalam K.A. 2010. Effects of amino acids in cotton seeds against the resistance to Fusarium wilt diseases. Allelopathy Journal 26 (1): 83-90.

Bakry M.A., Rizk R.H. 1967. Seed transmission of Fusarium oxysporum f. sp. vasinfectum, the causal agent of cotton wilt in the United Arab Republic. Agricultural Research (Cairo) 45: 1-4.

El-Ghamry A.M., Abd El-Hai K.M.A., Ghoneem K.M. 2009. Amino and humic acids promote growth, yield and disease resistance of faba bean cultivated in clayey soil. Australian Journal of Basic and Applied Sciences 3 (2): 731-739.

Gałązka A. 2013. Przemiany związków fenolowych a rola amoniakoliazy L-fenyloalaninowej (PAL) w indukcji mechanizmów obronnych rośliny. [Conversion of phenolic compounds and the role of L-phenylalanine amonia lyase (PAL) in the induction of plant defense mechanisms]. Polish Journal of Agronomy 15: 83-88.

Hasabi V., Askari H., Alavi S.M., Zamanizadeh H. 2014. Effect of amino acid application on induced resistance against citrus canker disease in lime plants. Journal of Plant Protection Research 54 (2): 144-149. DOI: 10.2478/jppr-2014-0023.

Homma Y., Shida T., Misato T. 1973. Studies on the control of plant diseases by amino acid derivatives. (1) Effect of N-lauroyl-L-valine on rice blast. Annales of the Phtopathological Society of Japan 39 (2): 90-98.

Kadotani N., Akagi A., Takatsuji H., Miwa T., Igarashi D. 2016. Exogenous proteinogenic amino acid induce systemic resistance in rice. BMC Plant Biology 16: 60. DOI: 10.1186/s12870-016-0748-x.

Kuć J., Barnes E., Daftsios A., Williams E.B. 1959. The effect of amino acids on susceptibility of apple varieties to scab. Phytopathology 49: 313-315.

Lipson D.A., Näsholm T. 2001. The unexpected versatility of plants: organic nitrogen use and availability in terrestrial ecosystems. Oecologia 128 (3): 305-316. DOI: 10.1007/s004420100693.

Mehta A., Mehta P., Chopra S. 1991. Effect of various nitrogenous sources on the production of pectolitic and cellulolytic enzymes by Fusarium oxysporum and F. moniliforme. Zentralblatt für Microbiologie 146 (6): 393-398. DOI: 10.1016/S0232-4393(11)80264-7.

Sarosh B.R., Sivaramakrishnan S., Shetty H.S. 2005. Elicitation of defense related enzymes and resistance by L-methionine in pearl millet against downy mildew disease caused by Sclerospora graminicola. Plant Physiology and Biochemistry 43 (8): 808-815. DOI: 10.1016/j.plaphy.2005.06.009. 
Tzeng D.D., Tzeng H.C., Chen R., Cheng A., Tsai C.C., Chen C., Hwang T., Yeh Y., DeVay J.E. 1996. The use of MR formulation as a novel and environmentally safe photodynamic fungicide for the control of powdery mildew. Crop Protection 15 (4): 341-347.

Van Andel O.M. 1966. Amino acids and plant diseases. Annual Review of Phytopathology 4 (1): 349-368. DOI: 10.1146/annurev. py.04.090166.002025.

Wojdyła A.T. 2017. Możliwość wykorzystania środków zawierających aminokwasy w ochronie róż przed Podosphaera pannosa oraz ich wpływ na rozwój roślin. [Possibilities of using products containing amino acids in the protection of roses against Podosphaera pannos $a$ and their influence on plant development]. Progress in Plant Protection 57 (1): 82-87. DOI: 10.14199/ppp-2017-014.

Wojdyła A.T., Sobolewski J. 2016. Możliwość wykorzystania środków zawierających aminokwasy w ochronie fasoli przed zgnilizną twardzikową. [The possibility of using products containing amino acids in the protection of bean against Sclerotinia sclerotiorum]. Zeszyty Naukowe Instytutu Ogrodnictwa 24: 131-140.

Woltz S.S., Jones J.P. 1970. Effects of twenty natural amino acids on pathogenesis of Homestead 24 tomato by Fusarium oxysporum f. sp. lycopersici races 1 and 2. Florida State Horticultural Society 83: 175-179. 